\title{
Rangelands and Ecosystem Services: Economic Wealth From Land Health?
}

\section{By Richard L. Knight, Jim Thorpe, and Lori Hidinger}

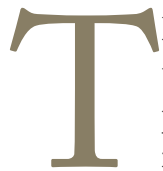

he Millenium Ecosystem Assessment ${ }^{1}$ captured the dynamic interplay of an expanding human population and rising standards of living on a finite planet in which lands and waters continue to degrade. The hundreds of scientists involved in the report concluded that some $60 \%$ of ecosystem services (ES) that all life depend on, including humans and their economies, are degraded and being used in ways that cannot be sustained.

Given this sobering assessment of life on Earth, it is not surprising that efforts to evaluate ecosystem services and find ways to incorporate them into our economies are gaining momentum. Approximately 31\% (750 million acres) of the United States consists of public and private rangelands. ${ }^{2}$ Though many of these areas have variable precipitation and nutrient-poor soils, it is staggering to imagine the amount and types of ES on these lands that sustain life, power our economies, and provide abundant amenities. To that end we present a set of serendipitous articles that focus on ES on rangelands in the United States.

Aldo Leopold ${ }^{3}$ wrote,

I plead for public encouragement, economic and moral, for the landowner that conserves the public values-economic and esthetic - of which he is the custodian. The search for practicable vehicles to carry that encouragement is... a soluble one.... Those charged with the search for such a vehicle must first seek to intellectually encompass the whole situation.

This is the theme of the first article by Goldstein et al., who explore payments for ES (PES), both the possibilities and the problems. They discuss what types of ES emanate from healthy rangelands, who the potential buyers are, and the components of a workable "vehicle" to consummate these transactions.

The role of the private sector as buyers in PES schemes is one of the big "elephants in the room." Although private investment has been limited to date (though not inconsequential), many analysts see substantial, albeit highly uncertain, growth potential. Why? The key reason is that companies are increasingly understanding how nature affects their bottom line, and believing that proactively integrating ES into their business planning can give them a competitive advantage. There is much activity on this front, including the recent establishment of a partnership between The Nature Conservancy and Dow Chemical to assist Dow and other companies with incorporating ES into their global operations. What these private sector opportunities mean for the rangelands community is a key question, and one for which there are many opportunities to be involved in shaping the answer to.

A recent and noteworthy development in public sector PES initiatives has been the advent of the Natural Resources Conservation Service's Conservation Stewardship Program. Mandated by the 2008 Farm Bill, this successor to the Conservation Security Program (CSP) is an ambitious nationwide program with a goal to recognize and monetarily reward the provisioning of existing ES and incentivize additional conservation performance on up to 130 million acres of the nation's farm and ranch lands over a 10 -year period. Utilizing the novel and comprehensive Conservation Measurement Tool (CMT), applicants under this competitive program are assessed and ranked for both present and projected performance under such broad ES categories as air quality, water quality, wildlife habitat, soil erosion, and energy. Awardees receive 5-year contracts with an option for a 5-year renewal contingent upon review; payments vary subject to total CMT conservation scores and CSP funding formulas, with individual caps of $\$ 40,000$ per year.

Arguably the first comprehensive effort to establish a PES regime that meaningfully includes rangelands, its impact to date has not been insignificant. Preliminary analysis from the first three contract periods (2009-2011) shows over 850 range operations, involving over 5 million private acres and earning more than $\$ 20,000,000$ in CSP payments (with an average rangeland CSP payment estimated at \$7/acre, vs. \$29/acre for croplands). 
Toombs et al. explore opportunities that improve the health of ranch lands and, importantly, how to capitalize financially by selling these improvements to buyers of ES. The approach used is a modification of World Resources Institute's Corporate Ecosystem Services Review. They present an intriguing look at the intersection of ranching, ecology, and economics, and why it matters if ranching is to retain its resiliency into an uncertain future.

Gosnell and colleagues explore ranchers' perspectives on market-based approaches to sequestering carbon on their rangelands and present a specific example, the Trigg Ranch in northeastern New Mexico. They provide an assessment of where carbon sequestration stood only a few years ago, while candidly admitting the Chicago Climate Exchange is presently moribund. Given that $80 \%$ of the private land in the 11 western states is presently being grazed by livestock, the role of healthy rangelands in mitigating warming temperatures will not be discounted much longer. This paper will be a "must-read" by landowners contemplating selling carbon credits when we once more appreciate the heat-trapping capacity of increasing atmospheric carbon dioxide.

The Trigg Ranch story is an interesting vignette of a family that manages a large ranch with emphasis placed on continuity and sustainability of a way of life rather than maximizing short-term profits. It covers how the ranch changed its ranching approach over time while also selling carbon credits to an energy company. The story is a compelling look at the challenges and obstacles that must be surmounted in marketing an ES.

Maczko et al. present a preliminary question-based framework developed by the Sustainable Rangelands Roundtable for use by ranchers, technical service providers, and other land managers who seek to identify and consider the potential of rangeland ecosystem goods and services provided by their lands.

Aldo Leopold wrote in 1934 that

The crux of the problem is that every land-owner is the custodian of two interests, the public interest and his own. What we need is a positive inducement or reward for the landowner who respects both interests in his land-practice... What should this reward be? What is a practical vehicle for it? These are the two basic questions in American conservation. ${ }^{4}$

Ranchers are compensated for the livestock (their private interest) that come from their ranch lands but heretofore have seldom been compensated for the public interests that well-stewarded lands produce: ES. These articles embrace Leopold's challenge in exploring what it will take for our society to compensate ranchers for nature's attributes, which are essential to our health and enrich our lives through amenities. These papers add to a growing body of thought on ES, which for both buyers and sellers is anything but academic!

\section{References}

1. Millennium Ecosystem Assessment. 2005. Ecosystems and human well-being: synthesis. Washington, DC, USA: Island Press.

2. Havstad, K. M., D. P. C. Peters, R. Skaggs, J. Brown, B. Bestelmeyer, E. Fredrickson, J. Herrick, and J. Wright. 2007. Ecological services to and from rangelands of the United States. Ecological Economics 64:261-268.

3. Leopold, A. 1935. Land pathology. In: S. L. Flader and J. B. Callicott [eDs.]. The River of the Mother of God and other essays by Aldo Leopold. Madison, WI, USA: University of Wisconsin Press. p. 212-217.

4. Leopold, A. 1934. Conservation economics. In: S. L. Flader and J. B. Callicott [EDs.]. The River of the Mother of God and other essays by Aldo Leopold. Madison, WI, USA: University of Wisconsin Press. p. 193-202.

Authors are Professor, Dept of Human Dimensions of Natural Resources, Warner College of Natural Resources, Colorado State University, Fort Collins, CO 80523, USA, knight@warnercnr. colostate.edu (Knight); Rancher, Newkirk, NM 88431, USA (Thorpe); and Managing Director, Consortium for Science, Policy \& Outcomes, Arizona State University, Tempe, AZ 85287, USA, and Editor, Rangelands (Hidinger). 